\title{
KAVAFIS AND MISES: MEANS AND END
}

\author{
SPYROS MALLIOS*
}

Fecha de recepción: 3 de noviembre de 2012.

Fecha de aceptación: 19 de diciembre de 2012.

MISES

\section{Means and End as Abstract Methodical Tools}

\author{
Mises stated ${ }^{1}$ that in his theory of human action he starts from \\ the axiom that an individual $I_{1}$.
}

* Graduate student, Máster en Economía de la Escuela Austriaca, Universidad Rey Juan Carlos. The idea of this paper was formed when Professor Jesús Huerta de Soto presented the different points of view between Kavafis and Mises in a lecture at the Rey Juan Carlos University at the 25th of October of 2012. I would like to thank the Lilian Voudouri Foundation (Athens, Hellenic Republic) for the scholarship it provided me for my graduate studies at Universidad Rey Juan Carlos for the academic year $2012 / 2013$.

1 «To act means: to strive after ends, that is, to choose a goal and to resort to means in order to attain the goal sought.» Mises, Ludwig von, 2002 [1962], The Ultimate Foundation of Economic Science, p. 4, New York: Foundation for Economic Education.

«The sciences of human action start from the fact that man purposefully aims at ends he has chosen.», Mises, Ludwig von, 2007 [1957], Theory and History, p. 3, Auburn, Alabama, USA: Ludwig von Mises Institute.

«The result sought by an action is called its end, goal, or aim. [...] A means is what serves to the attainment of any end, goal, or aim.», Mises, Ludwig von, 1966 [1949], Human Action, p. 92, San Francisco: Fox \& Wilkes, Fourth Revised Edition.

"Value is the importance that acting man attaches to ultimate ends. Only to ultimate ends is primary and original value assigned. Means are valued derivatively according to their serviceableness in contributing to the attainment of ultimate ends. Their valuation is derived from the valuation of the respective ends. They are important for man only as far as they make it possible for him to attain some ends.» Mises, Ludwig von, 1966 [1949], Human Action, p. 96, San Francisco: Fox \& Wilkes, Fourth Revised Edition. 
1. Chooses a certain end $E_{1}$ and puts aside other ends $E_{2}, E_{3}, \ldots$, $E_{\mathrm{n}}$ that he considers he could choose instead of the end $E_{1}$, and

2. He chooses, among the means $M_{1}, M_{2}, M_{3}, \ldots, M_{\mathrm{n}}$ which he considers will enable him to attain his chosen end, the means $M_{1}$ which he prefers and puts aside the other means $M_{2}, M_{3}$, $\ldots, M_{\mathrm{n}}$ that he considers he could choose instead of the means $M_{1}$. (The Axiom of Human Action)

Mises considers the terms End and Means abstract methodical tools which an individual may use to analyse human action. In other words, Mises does not consider something to be a Means or an End by itself (in an objective sense), but it is an individual who may consider it a Means or an End.

A means is what serves to the attainment of any end, goal, or aim. Means are not in the given universe; in this universe there exist only things. A thing becomes a means when human reason plans to employ it for the attainment of some end and human action really employs it for this purpose. Thinking man sees the serviceableness of things, i.e., their ability to minister to his ends, and acting man makes them means. It is of primary importance to realize that parts of the external world become means only through the operation of the human mind and its offshoot, human action. External objects are as such only phenomena of the physical universe and the subject matter of the natural sciences. It is human meaning and action which transform them into means. ${ }^{2}$

\section{Means and End as Achronical Methodical Tools}

Moreover, Mises considers the terms End and Means as achronical (out of time) methodical tools. Therefore, an individual $I_{1}$ may consider an action of his an End and a Means at the "same time».

For example:

2 Mises, Ludwig von, 1966 [1949], Human Action, p. 92, San Francisco: Fox \& Wilkes, Fourth Revised Edition. 
1. Individual $I_{1}$ wants to go for a trip and he chooses $D_{1}$ as his end (destination) and he puts aside $D_{2}, D_{3}, \ldots, D_{\mathrm{n}}$ that he considers he could choose instead of the end $D_{1}$.

2. However, individual $I_{1}$ does not want to go to $D_{1}$ merely because he wants to be there. He wants to go to $D_{1}$ in order to attain a chosen end $E_{1}$ (e.g. to be entertained, to meet a certain individual, to participate in recreational activities or for another purpose). Therefore, $D_{1}$ is now considered a means that individual $I_{1}$ chose in order to attain his end $E_{1}$.

On the other hand:

3. Individual $I_{1}$ needs to choose, among the means $T_{1}, T_{2}, T_{3}, \ldots$, $T_{n}$ which he considers will enable him to attain his chosen end $D_{1}$ (e.g. travelling by airplane, train, car, bicycle, walking or an other means), a means of transportation $T_{1}$ which he prefers and to put aside the other means $T_{2}, T_{3}, \ldots, T_{\mathrm{n}}$ that he considers he could choose instead of the means $T_{1}$.

In summary, individual $I_{1}$ :

1. Chooses end $E_{1}$ and puts aside other ends $E_{2}, E_{3}, \ldots, E_{\mathrm{n}}$ that he considers he could choose instead of the end $E_{1}$.

2. Chooses, among the means $D_{1}, D_{2}, D_{3}, \ldots, D_{n}$ which he considers will enable him to attain his chosen end $E_{1}$, the means $D_{1}$ which he prefers and puts aside the other means $D_{2}, D_{3}, \ldots, D_{\mathrm{n}}$ that he considers he could choose instead of the means $D_{1}$.

3. Chooses, among the means $T_{1}, T_{2}, T_{3}, \ldots, T_{\mathrm{n}}$ which he considers will enable him to attain his chosen end $D_{1}$, the means $T_{1}$ which he prefers and puts aside the other means $T_{2}, T_{3}, \ldots$, $T_{n}$ that he considers he could choose instead of the means $D_{1}$.

Therefore, in this example $D_{1}$ is considered by individual $I_{1}$ a means and an end at the "same time».

Human life is an unceasing sequence of single actions. But the single action is by no means isolated. It is a link in a chain of 
actions which together form an action on a higher level aiming at a more distant end. Every action has two aspects. It is on the one hand a partial action in the framework of a further-stretching action, the performance of a fraction of the aims set by a more farreaching action. It is on the other hand itself a whole with regard to the actions aimed at by the performance of its own parts. ${ }^{3}$

\section{II \\ KAVAFIS}

Kavafis states ${ }^{4}$ :

When you start on the way to Ithaca, wish that the way be long, full of adventure, full of knowledge. The Laestrygones and the Cyclopes and angry Poseidon, do not fear: such, on your way, you shall never meet if your thoughts are lofty, if a noble emotion touch your mind, your body. The Laestrygones and the Cyclopes and angry Poseidon you shall not meet if you carry them not in your soul, if your soul sets them not up before you.

Wish that the way be long, that on many summer mornings, with great pleasure, great delight, you enter harbours for the first time seen; that you stop at Phoenician marts, and procure the goodly merchandise, mother-of-pearl and corals, amber and ebony, and sensual perfumes of all kinds, plenty of sensual perfumes especially;

\footnotetext{
${ }^{3}$ Mises, Ludwig von, 1966 [1949], Human Action, p. 45, San Francisco: Fox \& Wilkes, Fourth Revised Edition.

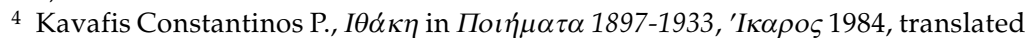
by George Valassopoulo and published as Ithaca in The Criterion 2/8 in July 1924, available at www.cavafy.com. Ithaki was written in 1911.
} 
to wend your way to many Egyptian cities, to learn and yet to learn from the wise.

Ever keep Ithaca in your mind, your return thither is your goal. But do not hasten at all your voyage, better that it last for many years;

And full of years at lenght you anchor at your isle rich with all that you gained on the way; do not expect Ithaca to give you riches.

Ithaca gave you your fair voyage.

Without her you would not have ventured on the way.

But she has no more to give you.

And if you find Ithaca a poor place, she has not mocked you.

You have become so wise, so full of experience that you should understand already what these Ithacas mean.

Kavafis (1863-1933) uses the story of Odysseus, who needed 10 years to return to his home in Ithaki from Troia, as a metaphor for our lives. He presents a more distant end (e.g. success, happiness, prosperity) as Ithaki island and our actions to achieve it (intermediate ends, means) as a voyage toward Ithaki. The central message is that an individual should not concentrate too much on his more distant end, because he will lose the opportunity to enjoy the actions he takes in order to achieve intermediate ends (Means). Kavafis, like Mises, considers an action both as a means in order to achieve a more distant end and as an end.

\section{Means and End, Cause and Effect}

If individual $I_{1}$

1. Chooses a certain end $E_{1}$ and puts aside other ends $E_{2}, E_{3}, \ldots$, $E_{\mathrm{n}}$ that he considers he could choose instead of the end $E_{1}$, and

2. He chooses, among the means $M_{1}, M_{2}, M_{3}, \ldots, M_{\mathrm{n}}$ which he considers will enable him to attain his chosen end, the means 
$M_{1}$ which he prefers and puts aside the other means $M_{2}, M_{3}$, $\ldots, M_{\mathrm{n}}$ that he considers he could choose instead of the means $M_{1}$ (The Axiom of Human Action)

then he would act $M_{1}$ in order to achieve $E_{1}$, because he considers $M_{1}$ to be a cause of the effect $E_{1}$. However, $M_{1}$ may cause other effects $F_{1}, F_{2}, F_{3}, \ldots, F_{\mathrm{n}}$ as well.

Kavafis states that the voyage (cause, means $M_{1}$ ) will cause

- the effect reaching Ithaki (effect, end $E_{1}$ ),

- the effect adventures (effect $F_{1}$ )

- the effect knowledge (effect $F_{2}$ )

- the effect visiting new places (effect $F_{3}$ )

- the effect tough times (effect $F_{4}$ ) (Laestrygonians and Cyclopes)

- the effect pleasure (effect $F_{5}$ )

- the effect joy (effect $F_{6}$ )

- the effect $F_{\mathrm{n}}$

Therefore, from all effects only one is chosen as an end.

\section{Means, End, Cause, Effect and Time}

Above I said that if an individual $I_{1}$ acts $M_{1}$ the effects will be $E_{1}, F_{1}, F_{2}, F_{3}, \ldots, F_{\mathrm{n}}$. If, however, he could reach his End $E_{1}$ instantly he wouldn't be able to experience the effects $F_{1}, F_{2}, F_{3}, \ldots, F_{\mathrm{n}}$.

Therefore, Kavafis said that an individual should hope his voyage (Means $M_{1}$ in order to achieve a more distant end $E_{1}$ ) to be a long one, because the longer the voyage the more effects $F_{1}$, $F_{2}, F_{3}, \ldots, F_{n}$ will be caused by $M_{1}$. His advice to the acting individual is to enjoy those effects, e.g. to consider them ends.

Even if an acting individual faces a lot of difficulties and disappointments (Laestrygonians and Cyclopes) when he tries to achieve a more distant end, he should not try to reach his more distant end as quickly as possible in order to avoid those tough times, because tough times are a valuable experience (an End), something which an individual can benefit from. 
Nevertheless, an individual should never forget his more distant end. This is what gives meaning to each of his actions (means and end) However, once he has attained his more distant end, he will realise that this is only «a part of the value». He will then understand what Ithacas (more distant ends) mean.

\section{BIBLIOGRAPHICAL REFERENCES}

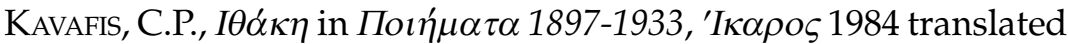
by George Valassopoulo and published as Ithaca in The Criterion 2/8 in July 1924, available at www.cavafy.com.

Mises, Ludwig von, (1966 [1949]): Human Action, San Francisco: Fox \& Wilkes, Fourth Revised Edition.

- (2002 [1962]): The Ultimate Foundation of Economic Science, New York: Foundation for Economic Education.

- (2007 [1957]): Theory and History, Alabama: Ludwig von Mises Institute. 